\title{
COMPETENCY AND VALUES OF LOCAL WISDOM OF HIGH SCHOOL PRINCIPALS
}

\author{
Yohanes Harsoyo*, C. Wigati Retno Astuti, Caecilia Wahyu Estining Rahayu \\ Universitas Sanata Dharma, Indonesia \\ *e-mail: harsoyo@usd.ac.id
}

\begin{abstract}
The competency of secondary school principals needs to be developed. The development of school principals' competencies needs to pay attention to cultural aspects that develop in the surrounding community. This research was aimed to describe the school principal's competencies according to National Education Ministry Regulation No. 13 (2007) about School Principal's standard competencies and their competencies development based on the values of local wisdom. This piece of research was conducted quantitatively and qualitatively. The research samples were 30 school principals whom their schools were located in the regional of Mataraman cultures. Data was gathered by collecting questionnaires (open and closed questions) and also interviews. The data was analyzed quantitatively and qualitatively. The results of this study are as follows: first, the school principals have been good at social and personality competences, yet the managerial, entrepreneurial, and supervision competences were still in adequate level; second, school principals already comprehended the values of Sistem Among and some of them had been implemented them. However, they had not been comprehend the leadership values based on Asta Brata and Sastra Gending; third, most of leadership values were based on Asta Brata, Sistem Among, and Sastra Gending that were compatible to the school principals and used for developing their leadership.
\end{abstract}

Keywords: principals' competences, asta brata, sistem among, sastra gending

\section{KOMPETENSI DAN NILAI-NILAI KEARIFAN LOKAL KEPALA SEKOLAH MENENGAH}

\begin{abstract}
Abstrak: Kompetensi kepala sekolah menengah perlu dikembangkan. Pengembangan kompetensi kepala sekolah perlu memerhatikan aspek-aspek budaya yang berkembang di masyarakat sekitarnya. Penelitian ini dimaksudkan untuk mendeskripsikan kompetensi kepala menurut Permendiknas No. 13 (2007) tentang Standar Kompetensi Kepala Sekolah/Madrasah dan pengembangan kompetensi kepala sekolah berdasarkan nilai-nilai kearifan lokal. Penelitian ini dirancang dalam bentuk penelitian kuantitatif dan kualitatif. Jumlah sampel sebanyak 30 orang. Sekolah-sekolah yang dipilih merupakan sekolah-sekolah yang berada di wilayah yang secara kultural memiliki kultur Mataraman. Pengumpulan data dilakukan menggunakan kuesioner (tertutup dan terbuka) dan wawancara. Teknik analisis data dilakukan secara kuantitatif dan kualitatif. Hasil penelitian ini sebagai berikut: pertama, kepala sekolah sudah baik pada aspek kompetensi sosial dan aspek kepribadian, namun masih cukup pada aspek kompetensi manajerial, kompetensi kewirausahaan, dan aspek supervisi; kedua, kepala sekolah sudah memahami nilai-nilai ajaran Sistem Among bahkan sebagian sudah mengimplementasikannya, namun mereka belum memahami nilai-nilai kepemimpinan berdasarkan Asta Brata dan Sastra Gending; ketiga, sebagian besar nilai-nilai kepemimpinan berdasarkan ajaran Asta Brata, Sistem Among, dan Sastra Gending bersesuaian dengan kompetensi kepala sekolah dapat digunakan untuk mengembangkan kepemimpinan kepala sekolah.
\end{abstract}

Kata Kunci: kompetensi kepala sekolah, asta brata, sistem among, sastra gending

\section{INTRODUCTION}

Ministry of National Education formulates five dimensions of principals' competencies, namely personality, management, entrepreneurship, supervision, social (RoI,
2007). The principals' competencies are not just basic knowledge and skills, but it refers to the actual ability of someone to knowledge and skills in real-life practice at the school (Kin, Kareem, Nordin, \& Bing, 2017). Boyatzis (1982) states that 
competencies are related to an effective or great performance of someone in doing a job. Some studies show that as a school leader, a competent principal has a positive organizational impact on school, such as structure determination, plans, school goals, and classroom conditions reflected in procedures, policies, classroom learning experiences (Leithwood \& Jantzi, 1999), and collaborative culture in school (Demir, 2008). Competent principals have a positive impact on students, such as students' activities, both inside and outside the classroom, and teachers, such as the teachers' collective and personal efficacy (Demir, 2008). Several studies in Indonesia also show that competent principals' leadership has a positive impact on satisfaction of the quality of working life (Kaihatu \& Rini, 2007) and organizational commitment and extra-role behavior (Kaihatu \& Rini, 2007).

A principal even needs to experience local cultural values while keeps focusing on fulfilling national needs and global demands (Harto, 2014). His main tasks are to select and choose appropriate leadership values that are needed by the school and to transmit those values to both teachers and students. Moreover, a school principal is expected to be able to think globally and act by paying attention to the values of local wisdom. Some of research gave empirical evidences that local wisdom values were effective to be applied in school's learning context. Leksono, Rustaman, \& Redjeki (2015) reported that the application of the local wisdom based conversation biology courses has increased biodiversity literacy (investigate, develop the process skills, develop the concept mastery, and act by appreciating biodiversity) and has formed conservation characters. Wulandari \& Mundilarto (2016) reported that Physics' active learning tools of local wisdom based learning tournament type has effectively increased students' concept mastery and character values. Furthermore, Sumardjoko (2018) reported that the learning model of local wisdom based civic education was effective to improve character scores, national identity, and learning mastery. Those pieces of research showed that the implementation of local wisdom values was effective to obtain learning goals. Therefore, principals were supposed to be encouraged to implement local wisdom values through their leadership considering local wisdom values has advantages to obtain the education goals.

In Javanese culture contexts, Javanese conserve local wisdom not only in their minds, yet also in their senses. They do not only have ordinary experiences, yet also have some acts. In Java, local wisdom tends to be physically and spiritually central struggles to obtain salvation of life (Wagiran, 2011). It is no doubt that the values of culture and local wisdom has made Yogyakarta and Mataraman people polite, adaptable, acceptable, hardworking, forward thinking, and competitive. Based on history, local wisdom has supported the existence of a nation. Japan, South Korea, and German, for instance, show that their national values contributed to their country's advancement (Wagiran, 2011). Thus, learning about values of local wisdom and act those values is very important to gain the excellence of leaders, including the principals. This study aims to describe the competency of high school principals along with their local wisdom values and principals' leadership development based on local wisdom values. Consecutive values are (1) Asta Brata, (2) Sistem Among, and (3) Sastra Gendhing. The local wisdom-based school leadership is considered that it can encourage teachers to reflect their class activities, so they are motivated to improve their performance.

\section{METHODS}

This research is done in quantitative and qualitative approach with a survey method. The subject of the research is high school principals, both junior and senior high school, in Yogyakarta, Central Java, and East Java. The selected schools are located in the area which is culturally affected by Mataraman culture. Mataraman culture refers to an area which is influenced by the culture of Mataram Islam, including the culture of Surakarta and Yogyakarta, that are a fraction of Mataram Islam. The number of principals as the samples of this research is 30 schools, which are consist of 15 schools in Yogyakarta, 8 schools in Central Java, and 7 schools in East Java.

Data was gathered by collecting questionnaires (open-ended and closed-ended questions). The questionnaire itself is about school competencies according to Education Ministerial Regulation No.13/2007 on Competency Standards of School/Madrasah (Islamic Schools) Principals which is consist of social competency, personality competency, 
supervision competency, managerial competency, and entrepreneurial competency (RoI, 2007). Also, the questionnaire is about the values of local wisdom that are popular among the principals and the Javanese leader figures. The researcher used quantitative and qualitative analysis technique. The steps done were data condensation (selecting, simplifying, abstracting, transforming the data that approached the whole part from written field notes, interview transcripts, documents and any other empirical materials), data display (organizing, combining information for possible conclusions and actions), and conclusions (drawing conclusions and verifying) (Miles, Huberman, \& Saldana, 2014).

\section{RESULTS AND DISCUSSION Results}

The principal of this respondent were from 3 provinces. There were 15 people $(50 \%)$ from Yogyakarta, 8 people $(26.667 \%)$ from Central Java, and $23.333 \%$ from East Java. Those three provinces are located in the areas of Mataraman. Mataraman region refers to the area where in ancient times belonged to Mataram Sultanate (Mataram Islam). Thus, those provinces have similarity in the cultural values. The researcher took respondents from Kediri and Pacitan in East Java. Those regions are seen as an area that have a strong believer of Mataraman values. Meanwhile, the entire areas of Yogyakarta and Central Java are Mataraman regions. However, the researcher took respondents from Purworejo, Magelang, Surakarta, Yogyakarta, Bantul, Sleman, Gunung Kidul, and Kulon Progo. The researcher took 17 principals $(56.667 \%)$ from state school and 13 principals $(43.333 \%)$ from private school. In addition, the researcher selected various private schools affiliated to large organizations, such as Muhammadiyah, Nahdatul Ulama, Christian, and Catholic.

According to Education Ministerial Regulation No.13/2007 on Competency Standards of High School/Madrasah Principals (RoI, 2007), there are five competencies the principals must have, namely managerial competency, entrepreneurial competency, supervision competency, personality competency, and social competency. To reveal principals' competences, researcher distributed closed questionnaires to 30 respondents. The research result is presented in Table 1 . The description of principals' competencies which are related to managerial competency was adequate; principals' competencies on entrepreneurial was adequate; principals' competencies on supervision was adequate; principals' competencies on personality shows was good; principals' competencies on social was good. In general, the average of six principals' competencies was adequate.

Principals' understanding level of local wisdom was in line with their managerial competences as presented in Table 2. The research result showed that: 1) Most principals had not comprehended the leadership values based on Asta Brata; 2) Most principals had comprehended the leadership values based on Sistem Among, even some of them had implemented those values at school; 3) Most principals had not comprehended the leadership values based on Sastra Gending. The leadership values based on Sistem Among were more comprehensive because these values were often implemented as the education illustrations in Indonesia and were delivered in the trainings for principals.

Table 1. Description of Principals' Competencies

\begin{tabular}{lccccc}
\hline Competency & $\begin{array}{c}\text { Theoretical } \\
\text { range }\end{array}$ & Actual range & Average & Median & $\begin{array}{c}\text { Standard } \\
\text { deviation }\end{array}$ \\
\hline Management & $16-90$ & $32-73$ & 55.967 & 23 & 8.244 \\
Entrepreneurship & $5-25$ & $10-23$ & 17.763 & 8 & 2.763 \\
Supervision & $3-15$ & $6-15$ & 11.000 & 56 & 2.068 \\
Social & $3-15$ & $6-15$ & 11.967 & 17 & 2.042 \\
Personality & $6-30$ & $18-30$ & 23.200 & 11 & 3.527 \\
\hline
\end{tabular}


At the next level, researcher investigated the compatibility level of the local wisdom values with principals' managerial competences. In this piece of research, researcher created a brief elucidation of each local wisdom value and gave respondents opportunities to read and match local wisdom values that corresponded to principals' managerial competences (Table 3).

Table 2. The Description of Principals' Comprehension Level on Local Values of Managerial Competences

\begin{tabular}{lcccccc}
\hline $\begin{array}{l}\text { Values of } \\
\text { Local Wisdom }\end{array}$ & \multicolumn{5}{c}{ Principals' Comprehension Level } \\
\cline { 2 - 6 } & $\begin{array}{c}\text { Not } \\
\text { knowing }\end{array}$ & Ever heard & Ever read & $\begin{array}{c}\text { Understand } \\
\text { the contents }\end{array}$ & $\begin{array}{c}\text { Have implemented } \\
\text { them }\end{array}$ & Total \\
\hline Asta Brata & 6 & 8 & 12 & 4 & 0 & $(100 \%)$ \\
& $(20 \%)$ & $(26.67 \%)$ & $(40 \%)$ & $(13.33 \%)$ & 10 & 30 \\
Sistem Among & 0 & 0 & 3 & 17 & $(33.33 \%)$ & $(100 \%)$ \\
& $(0 \%)$ & $(0 \%)$ & $(10 \%)$ & $(56.67 \%)$ & 0 & 30 \\
Sastra Gending & 8 & 9 & 11 & 2 & $(0 \%)$ & $(100 \%)$ \\
\hline
\end{tabular}

Table 3. The Description of Local Wisdom Values Compatibility with Managerial Competences According to the Principals

\begin{tabular}{|c|c|c|c|c|c|}
\hline \multirow{2}{*}{$\begin{array}{c}\text { Local } \\
\text { Wisdom } \\
\text { Values }\end{array}$} & \multicolumn{5}{|c|}{ Managerial Competences } \\
\hline & Managerial & Entrepreneurial & Supervision & Social & Personality \\
\hline Asta Brata & $\begin{array}{l}\text { Laku hambeging } \\
\text { surya }\end{array}$ & $\begin{array}{l}\text { Laku hambeging } \\
\text { candra } \\
\text { Laku hambeging } \\
\text { samodra }\end{array}$ & $\begin{array}{l}\text { Laku hambeging } \\
\text { surya } \\
\text { Laku hambeging } \\
\text { dahana }\end{array}$ & $\begin{array}{l}\text { Laku hambeging } \\
\text { samirana }\end{array}$ & $\begin{array}{l}\text { Laku hambeging } \\
\text { kisma }\end{array}$ \\
\hline $\begin{array}{l}\text { Sistem } \\
\text { Among }\end{array}$ & $\begin{array}{l}\text { Ing ngarsa sung } \\
\text { tuladha } \\
\text { Ing madya } \\
\text { mangun karsa }\end{array}$ & $\begin{array}{l}\text { Ing madya mangun } \\
\text { karsa }\end{array}$ & $\begin{array}{l}\text { Ing ngarsa sung } \\
\text { tuladha } \\
\text { Ing madya } \\
\text { mangun karsa } \\
\text { Tut wuri } \\
\text { handayani }\end{array}$ & $\begin{array}{l}\text { Tut wuri } \\
\text { handayani }\end{array}$ & $\begin{array}{l}\text { Ing ngarsa sung } \\
\text { tuladha }\end{array}$ \\
\hline $\begin{array}{l}\text { Sastra } \\
\text { Gending }\end{array}$ & $\begin{array}{l}\text { Ruktisetya } \\
\text { garbarukmi }\end{array}$ & $\begin{array}{l}\text { Bahnibahna } \\
\text { amurbeng jurit }\end{array}$ & & $\begin{array}{l}\text { Stiranggana cita } \\
\text { Smarabhumi } \\
\text { adimanggala }\end{array}$ & $\begin{array}{l}\text { Sripandayasih } \\
\text { krani }\end{array}$ \\
\hline
\end{tabular}

\section{Discussion}

\section{Principals'Managerial Competences and Local Wisdom Values}

The research result showed that the principals' managerial competences, such as principals' competence to manage the resources by planning, organizing, directing, and monitoring to obtain school's goal effectively, was considered adequate. This finding illustrated that the principals had not had appropriate strategies to empower educational staffs, to give them opportunities to elevate their professions, and to encourage them to engage in some school program activities effectively and efficiently.

In this piece of research, it was found that there were 4 managerial competence indicators that relatively difficult to be implemented by principals consecutively: 1) managing changes and school's development to more effective learning organization; 2) managing teachers 
and school staffs in order to empower human resources optimally; 3) monitoring, evaluating, and reporting the school's program activities; and 4) leading the school in order to empower school resources optimally. Managerial competences were indeed not easy to done by principals since they were teachers who received additional tasks to be principals. Generally, they have not had specific competences to be leaders or managers. Most of them were promoted to be principals after being considered having good performance as teachers. As a result, the principals had low productivity due to lack of productivity and experiences in order to improve the quality of education at school.

However, the principal has a strategic role in determining school strategies, plans, and management practices to develop academic culture in schools (Tian, Risku, \& Collin, 2015). To develop good management strategies, they require both technical and non-technical competence. Principal competencies will affect the quality of decisions and define actions in school education practice. Through the time, good actions and practices will affect teachers' beliefs through the transformation of school culture (Macneil, Prater, \& Busch, 2009). Therefore, principals' managerial competences as seen in the research above needs to develop more and be in line with the local values in society.

First, in cultural context, principals' managerial competences corresponded to the values in puppet show known as Asta Brata. Asta Brata has eight values to recognize individuals and to underlie the leaders to manage a good government based on natural characters. From eight of Asta Brata's values, the most compatible value is Laku Hambeging Surya. This value's meaning is that a leader has to inspire their people, like a sun shines and energizes all beings on earth. The sun has become the source of life for all beings to live and grow. In educational context, a principal, as a leader, has carried an ability to encourage and foster learning and work enthusiasm for teachers, staffs, and students so that they can execute a good learning process. The sun shines bright endlessly and illuminates indiscrimately. Hence, a principal must be able to enlighten students, teachers, and staffs and to act carefully like a sun that moves with ease, patiently, yet still gives its light (like directions, teachings, guidance, and values) to all fairly and unconditionally. A principal also becomes a model to work professionally and creatively as well as has integrity as an effective teacher and learner. For instance, a principal can be a role model of teachers, staffs, and students to be always honest, disciplined, fair, uphold the dignity or honor of others, and become an intelligent figure in managing students, teachers, staffs, and institution as well as can be wise to face various problems occur at school and provide the best alternative solutions for all. If an effective learner's organization is well-created, then there will be good causes to support the learning and teaching process. The sun is therefore considered to provide life force to work. Meanwhile, the character of the sun that shines all earth to live has meaning for the principals to always have positive energy and high spirit of life in carrying out their duties and functions. With the positive energy and high spirit of life, the principals are able to carry out their duties and functions to encourage teachers, staffs, and students to have more effective learning process.

Second, in cultural context, principals' managerial competences corresponded to the values known as Sistem Among (Dewantara, 1930). These values were formerly taught by the most famous Indonesia's education figure, Ki Hadjar Dewantara. Sistem Among's values are often used as a reference for implementing education in Indonesia. The first local wisdom value that corresponds to the managerial competences is ing ngarsa sung tuladha. This value is not only applicable in education, yet in every single aspect of life. It has a deep meaning that a leader is positioned in the front as a role model. If this slogan is applied at school, so the principal is expected to be a role model for teachers, staffs, and students. Principal's behaviors and attitudes will affect teachers, staffs, and students effectively instead of only in words. The behaviors and attitudes are shown, for instance, by coming to school earlier and coming home last and by being patient, wise, honest, fair, and firm in solving problems of students, teachers, or staffs, as well as by giving the best smile, greeting anyone he meets, and having smooth and polite speech. The second local wisdom value is ing madya mangun karsa. This value means that a leader at school must be able to provide high enthusiasm in building confidence 
of students, staffs, and teachers to strive on behalf of the school. One of the success benchmarks of principals is able to motivate and encourage students to study diligently and consider that studying at school is a lot of fun. Teachers also need to be motivated and supported since they may feel tired and bored which can affect to their productivity and performance, both inside class and outside class. Any kinds of motivation can be given, for instance, accommodating school facilities such as comfortable computer rooms with the latest computer sets, cool library with complete and enticing collections, scholarships for excellent students and also subsidies for students who are economically disadvantaged. Teachers need to periodically be refreshed by conducting outing, sending them for seminars or workshops, and training about teaching methods and new abilities in order to enrich the sources of materials and teaching methods so that the class will be more positive and exciting.

Third, in cultural context, principals' managerial competences corresponded to the values known as Sastra Gending. These values was formerly written down by the Third Mataram Kingdom King, Sultan Agung Hanyokrokusumo (or Raden Mas Jatmika) who was born in 1593 and ruled in 1613 - 1645. This leadership philosophy has been applied by Sultan Agung during his reign as King of the Islamic Mataram kingdom, and this philosophy also led him to successfully lead his kingdom and even unite almost the entire island of Java under Mataram's rule. One of the values of Sastra Gending that corresponds to managerial competences is Rukti Setya Garba Rukmi. Based on this, a principal must have a determination to direct all school resources for the prosperity and dignity of all teachers and students. Its resources can be: school programs, curriculum, human resources (teachers, educational or non-educational staffs, students, parents, and communities who are related and have a concern to the school), as well as physical resources, such as buildings, rooms, equipments, study time, and financial resources.

\section{Principals' Entrepreneurial Competences and Local Wisdom Values}

The research result showed that the principals' entrepreneurial competences, such as the nature, characters, and characteristics of individuals and also having a strong willingness to realize and develop creative and innovative idea into valuable activities, were categorized adequate. This finding pictured out that the principals had not possess entrepreneurial skills, especially on creative thinking and innovative acts. The finding of the study reveals that there were two indicators of entrepreneurial competence that were considered difficult to do, namely: (1) having entrepreneurial instincts in managing schools' activities as a source of students' learning; and (2) creating innovations that were useful for the schools' development. The principal is a teacher who has many experiences as a teacher. The entrepreneurial spirit is not much developed on their career as a teacher. Therefore, the biggest challenge for the principals is to create useful innovations for schools. They feel overwhelmed enough to accommodate changes which come from government, especially those which are related to curriculum and administration.

The entrepreneurial characteristic involves three dimensions, namely innovation, risk taking, and proactive (Departemen Pendidikan Nasional, 2007). In line with that research finding, entrepreneurial competences need to develop based on values of local wisdom. First, in cultural context, principals' entrepreneurial competences corresponded to the values of Asta Brata: Laku Hambeging Candra and Laku Hambeging Samodra. Laku Hambeging Candra has profound teaching about one's ability to motivate others. Leaders must be able to give motivations to their people, like a moon that shines brightly at night for all beings on earth and makes the night so beautiful. Leaders, therefore, are supposed to give directions and solve any problems, encourage, and lift up others' spirits as well as grow the hopes when facing difficulties. In educational context, principals are supposed to be able to create a happy, peaceful, friendly, patient, affectionate, and authoritative atmosphere at school so that they will be respected by teachers, staffs, and students. Laku Hambeging Samodra, on the other side, has meaning as the one's ability to accommodate aspirations. Leaders are supposed to be able to accommodate aspirations, like the ocean that is ready to accommodate anything that is washed away from the land. The ocean reflects pluralism in the plural society, broad knowledge, and flat surface yet refresh. Leaders must place 
all of their people at the same degree and dignity. In educational context, principals have to be fair, wise, affectionate to all students, teachers, and staffs, as well as not to reject anyone who comes to them, to accept and accommodate anything, to be patient and to have good insights. Like the ocean, principals are supposed to have good heart, be patient, not be easily offended when being criticized, not carried away by flattery, and easily to forgive. Moreover, they need to be like water as well, which means they are easy to adapt and to give comfort to their people. As a symbol of binding power, the principal must be able to use his power to protect the entirety and integrity of the students, teachers, and staffs, and to protect them from all other forces that disturb the peace and security broadly and evenly.

Second, the principals' entrepreneurial competences corresponded to the values of Sistem Among, especially ing madya mangun karsa. Ing madya mangun karsa has meaning that a principal must give his ideas and initiatives to teachers, staffs, and students to obtain the schools' goals. He has to apply his creativity to solve the problems and look for the opportunity to develop the schools better. As an example, teachers are assigned for workshops of learning innovations in order to attract students actively in their learning process, to motivate educational staffs to think and act creatively, innovatively, and productively, and to sharp students' instinct of entrepreneurships by providing entrepreneurial facilities at school.

Third, the principals' entrepreneurial competences corresponded to the values of Sastra Gending, especially Bahni Bahna Amurbeng Jurit. Principals are supposed to be in the front and be a role model for teachers, staffs, and students in defense of justice and truth, and also to take initiatives. Based on this value, a principal who is good at words and rhetorical, yet does not act concretely, is not the real leader.

\section{Principals'Supervision Competences and Local Wisdom Values}

The research result showed that the principals' supervision competences, that is the principals' effort in leading teachers and staffs to improve teaching, including human resources development in schools, developing and updating educational goals, teaching materials, teaching methods, and teaching evaluations, were categorized adequate. This finding pictured out that the principals have not had adequate supervision competences to manage the educational resources at school in order to obtain the education goal. The finding of this research revealed that the principals found it difficult to follow up academic supervision results of teachers for improving their professionalism by academically supervising them using appropriate supervision approaches and techniques. The interviews revealed that: firstly, the principals feel that they have a lot of agendas to do, so they find it difficult to manage their time to do the supervision. Generally, time for supervision has been arranged and agreed by the principals and the teachers, but the principals cannot always make it due to their hectic schedule that makes them have to rearrange the time or cancel the supervision. In contrast, supervision on other aspects tend to the physical aspects that support the learning activity, such as fund management, employees, buildings, equipment and other facilities; secondly, changes in the old curriculum to the new curriculum demand changes in learning process. Teachers might have attended trainings on how they implement a new curriculum, but it is not enough. This condition causes the teachers ignorant about the implementation and they tend to ask the principals, while the principals feel incompetent enough to explain the answers. It often makes the principals feel unconfident in doing the supervision so the supervision tends to prioritize administrative technical aspects rather than academic aspects. In fact, the aspect which should be concerned is the quality of learning process in the school. Documents, notes, and teachers administrative reports are also important because it is used to obtain the overview of the learners' quality in the learning process; thirdly, the condition which the facilities owned by the institutions are limited, such as textbooks, props, laboratories, and other facilities. This also becomes the main reason why teachers find it difficult to change their teaching methods according to the curriculum.

The finding of this research was in line with the research from the Analytical and Capacity Development Partnership (ACDP). Based on the results of ACDP research on the competence which the principals must have, the 
cooperation of Indonesia, Australia, Europe, and Asian Development Bank to 4070 principals in 55 regencies from seven provinces in Indonesia, which are Sumatra, Java, Nusa Tenggara, Kalimantan, Sulawesi, Maluku, and Papua, reveal that the supervision competence is the most minimum competence owned by principals in Indonesia, compared to other competencies. The result of the supervision competence score is 3.00 from the scale of 1.00-4.00. Meanwhile, the result of other competence assessment is 4.00 for each competence (Kementrian Pendidikan dan Kebudayaan, 2013). This condition becomes a problem if the principals who do their duties as supervisor in teaching have low supervision competence. It will have an impact on its performance in improving teacher professionalism and the quality of education in schools. The principal will have difficulty in fostering, guiding, and improving the quality of the teaching process.

The finding of this research shows that the difficulties owned by teachers are reflected on how they manage the facilities and infrastructure of the school, develop the schools, manage the learners, utilize the technology, and prepare the school planning, and so on. The interviews show that: firstly, principals, particularly private schools, find it most difficult to manage facilities and infrastructure optimally. It is because private schools are autonomous and generally have very limited facilities and infrastructure. Meanwhile, the state schools have more facilities and infrastructure, but they cannot utilize it optimally because the infrastructure is easy to be broken due to the poor quality and poor maintenance; secondly, the principals often face the tension when they establish discipline and democracy. On the one hand, this establishment leave the teachers, staffs, and students do not have choice but obey. On the other hand, teachers must be democratic due to different periods; thirdly, the principals feel they are lack of the ability in monitoring system and its follow up, especially those which are related to the performance of the teachers and staffs. The principals feel that the implementation of those activities can lead to conflicts that cause an atmosphere of inharmoniousness; fourthly, the rapid changes in the environment. These changes include curriculum changes, administrative changes using computer systems, and other changes caused by the changing times. This is seen as a relatively difficult part because the change should be followed by changing habits and perspective. In line with this finding, the principals' competences are all needed to develop based on the values of local wisdom.

First, the principals' supervision competences correspond to the values of Asta Brata, especially Laku Hambeging Surya and Laku Hambeging Dahana. Generally, principals are worried that supervisions might cause negative effects to teachers, either relationship between teachers and principal or the school's environment or even it can trigger conflicts at school. On the other side, the principals have a hope that they will have good relationships with all teachers. In this case, they can adopt the values of Asta Brata, especially Laku Hambeging Surya. Like the sun that shines the earth, gives the energy to all beings, and make them to grow and thrive, then the principals have to continuously improve the supervision competences so that they can help the teachers who face difficulties in the work. Moreover, principals have to develop positive perception of supervision to teachers. Their recent perception tends to be an assessment from the principal to the teacher. Teachers, generally, feel afraid of any assessments and any follow-ups after the assessment done whereas supervisions should be done as a part of the learning process. A teacher is an on-going formation of profession; therefore, the improvement of competences should be strived for continuously. In other words, supervision is seen as one of the ways to improve the teachers' capabilities. Furthermore, principals also adapt the values of Laku Hambeging Dahana. These values are related to fire which burn, finish, and destroy. The nature of fire symbolizes the high work ethic so that every problem needs to be solved. Principals must also be able to uplift teachers' spirits and initiatives to finish the work thoroughly and responsibly. If during supervision, there is a teacher who acts arbitrarily, then the principal has to take a firm stand on him. On certain condition, a sanction must be taken for better and the teacher can work based on the set goals.

Second, the principals' supervision competences correspond to the values of Sistem 
Among, that is ing ngarso sung tuladha, ing madya mangun karsa, tut wuri handayani. Based on Sistem Among's values, supervision competences correspond particularly to ing ngarsa sung tuladha. Principals are supposed to be the role model who inspires others. The principal can be a role model if he is always lively and enthusiastic about his work, puts respect to other people, and to always give his best and work hard (Leithwood \& Jantzi, 2006). He can only be a role model only if he is able to act or behave right to be emulated by the subordinates. Supervision competences also correspond to the value of ing madya mangun karsa. A principal is always around his subordinates (teachers, staffs, and students). A principal must motivate, respect, and support them based on their needs. When the teachers feel respected by their leaders and receive personal support of their condition, they will eventually feel supported and it makes them to be more enthusiastic to work, even when the work is hard. Having the support, the teachers will feel confident to solve the problems, because they believe their leader is with them and will help them. Moreover, supervision competences also correspond to the values of tut wuri handayani. It means that when the principal is behind his subordinates, he is supposed to give support and influence them so that they are independent. There are some ways to give supports and influences, such as giving intellectual stimulation through reflected questions on learning practice done: has it the best way to help students learn or do they find any other way, use other up-to-date approaches to help students learn better? Besides, the principals give the information about new way or new information about latest learning practices. With questions and new information given, it may trigger teachers' awareness to improve their learning practices, such as learning strategies applied, ways to evaluate students, learning sources, etc. If this awareness has been formed, the principal's task is only to support so that the better learning process can be wellmaintained and continuously improved as well as to facilitate the teachers on the improvement plans. In some leadership studies of principals, the principal's leadership is commonly known as learning leadership to be able to design the learning plan, to execute it, and to evaluate it for students' learning success.

\section{Principals'Social Competences and Local Wisdom Values}

The research finding showed that the principals' managerial competences, that were the skills in attitude and cooperating with the social environment at school, were categorized good. This condition depicted the principals who already had skills and good relationship with the teachers, staffs, students, and social environment at school. These competences need to be maintained. Based on the interviews, the principals said that they were trying to be warm with teachers, staffs, students, and also to be friendly with the environment outside, such as the nosiness community, educational selfhelp organizations, and communities surround. Relationship between the outsiders are generally in the form of inter-institutional cooperation. On many occasions, the collaboration between outsiders and the schools are done because of the initiative of the outsiders, such as universities, businesses, and communities. The cooperation with universities is done in the form of Field Experience Practice program. The cooperation with business world is done in the form of cooperation in corporate study and sponsorship for school activities. The cooperation with communities is done by participating in the communities' events or activities. Principals generally do not have authority to reject any cooperation with outsiders. On the other hand, they are lack of initiative on how to optimize the cooperation so it can improve the quality of their schools.

The principals' ability to manage the relationships with outsiders, understanding the thoughts, feelings, perspectives, wider description, they need to be flexible in facing the change (Saxe, 2011). This attitude can predict the further attitude that can encourage reformation and positive performance in the school. Social competence is the antecedent of the transformational leadership in schools (Cerado \& Abdullah, 2015). Goleman, Boyatzis, \& McKee (2002) state that the individuals which have social awareness do not only need to understand, but also need to empathize with the others' perspectives, understand the wider descriptions due to decision-making and organizations' business. This skill is crucial in encouraging resonance as a leader who has an awareness of what others think and feel will make 
them easy to take decision in particular situations. However, the ability to manage relationship needs a combination of skills such as motivating others in the same vision of the organization and persuading the others through various tactics in order to support the development of skills, abilities, and new performance. Conflicts in relationships in social tasks are inevitable. The ability to deal with the conflicts effectively is very important in the relationship with people at school to encourage the organization to be better.

In cultural context, principals' social competences correspond to the values of Asta Brata, particularly Laku Hambeging Samirana. This value is related to the air as main source of life that is able to penetrate in any dimensions without any limit. A principal needs to know the conditions and stories of people who work as his subordinates so that he knows their needs, difficulties, and challenges faced by the subordinates in their work. By knowing them thoroughly, the principal can invent innovations and new ways to solve any problems.

Second, social competences correspond to the values of Sistem Among, especially tut wuri handayani. A principal needs to add more opportunities to have effective and conducive meeting with the teachers. In this term, the principal support teachers' work by being friendly, close, and considerate to teachers, both as an individual or as a team. The principal's instrumental behavior is oriented and clarified directly in the roles and tasks of the teachers, as an individual or as a team. His positive behavior can support, direct, and motivate all people at school to work hand-in-hand to achieve the school's vision, mission, and goals.

Third, social competences correspond to the values of Sastra Gending, particularly Stiranggana Cita and Smara Bhumi Adi Manggala. Based on the values of Stiranggana Cita, a leader acts as a conservationist and cultural developer, the light of knowledge originator and also the bearer of happiness for community. Culture and science are means of development for characters, intellectuality, and society view of life. If the society has good characters, high intellectuality, and broad view of life, so the nation will escalate and develop significantly. In line with this value, the principal has to maintain good, friendly, and warm relationship with staffs, teachers, and students.
It gives the happiness and add up the energy to run the school. Meanwhile, based on the values of Smara Bhumi Adi Manggala, a leader must be determined to maintain, be a pioneer of unifying various different concerns continuously, and play a role in creating peace in the world. Sometimes, there are conflicts at school between teachers, teacher and staff, or teacher/staff and student. A principal has to be unifier to create peace at school. By having peaceful environment, it is easier to achieve the goals.

\section{Principals' Personality Competences and Local Wisdom Values}

The research result showed that principals' personality competence, that was a personal characteristic such as the nature and attitude of a person related to one's behavior was categorized good. This condition depicted the principals had good traits, attitudes, and behaviors and was able to be role models for teachers, staffs, students, and school environment. However, the finding of this study shows that personality competence is a competence which is considered difficult by the principals. These are the personality competencies which are perceived as difficult consecutively: open, noble, integrity, strong desire, self-control, and having talent and interest. The interviews with the principals indicate that as school leaders, they have to be a good role model for teachers, staffs, and students. A principal has to believe that anyone who becomes a leader has to be a good role model for others. The model itself is not only about in words, but also in action which can be seen and felt by others in schools. For them, being a role model in the school is considered as a moral burden. They no longer feel as free as teachers. Among the various attitudes, being open is the most difficult attitude they do because they have a feeling of "ewuh pakewuh" which means that if something is wrong and say it is wrong, then it can hurt the others' hearts and it can lead to disharmony among the principal, teachers, and staffs at the school.

The finding explains why some characteristics of leaders and situations are related to the followers' perception of a leader as an ethical leader (Bandura, 1986, BrowneFerrigno \& Muth, 2004). In social learning theory, leaders are ethical leaders for their followers. Leaders must be an attractive and 
credible role model. Social learning theory also helps explain about why and how ethical leaders can influence their followers. Followers will pay attention and imitate the attitude, value, and behavior of an attractive and credible model (Bandura, 1986). Most individuals reflect what is outside their selves to other individuals for ethical guidance (Trevino, 1986; Halbusia, Tehseen, \& Ramayah, 2017). The ethical leader can be a source of guidance because of their attractiveness and credibility as role models. Power and status are two model characteristics which increase their attractiveness (Bandura, 1986), thus it makes the followers pay attention to the behavior of the models. Most leaders have authority because they have a position of status relative to their followers. However, attractiveness takes an important role more than power and status. Credibility also improves the effectiveness of the model. Ethical leaders can be trusted because they can be trusted and they are responsible in doing what they say. Therefore, if the leaders do not obey what they say, then there is no reason for others to do so (Bandura, 1986). Moreover, the finding of the research also shows that the principals have a burden to be a spiritual leader. When someone in a spiritual leadership position, it means having to be able to embody spiritual values such as integrity, honesty, and humbleness, become a person who can be trusted, relied, and admired. Spiritual leadership is also shown through behavior, either in individual reflective practice or in ethical, compassionate, and respecting others (Reave, 2005).

In local cultural context, first, personality competences correspond with the values of Sastra Gending, especially Laku Hambeging Kisma. The leadership trait is related to the nature of earth. The earth has a generous nature to anyone who deserves mercy according to his behavior. Everything on earth is available to fulfill all beings' needs. It is a place to accommodate all beings and has a strong and sacred nature. In relation to the principal, the principal is supposed to be steadfast and not easy be swayed by all the difficulties and obstacles and not to give up easily. A principal also must have a strong vision so that any decisions and actions will always go to the set goals. Like the generous earth that provides for the human, the principal has to think his people's prosperity prior to his own prosperity.
Second, personality competences correspond with the values of Sistem Among, especially ing ngarsa sung tuladha. A principal shall have integrity. With the integrity, he will be able to work wholly and consistently by having same and parallel thoughts, words, and actions. In school context, principals are often asked for their opinions in meetings, for giving speech, and even for creating a written regulation. The principal should act according to what he says. If the principal has thoughts, words, and actions in accordance with the noble values that live in society, then he is said to have noble character. By having good morals, the principal can be a role model for all students, all teachers, and all employees.

Third, personality competences correspond with the values of Sastra Gending, particularly Sripandayasih Krani. The principle has to be determined to preserve the sacredness of religion sources for the society. It is because religion is a media to form society's characters and ideal morals. Without the leader's obedience to religion, members of society tend to be undignified, immoral, and uncivilized. The destruction of society means the destruction of a country. Therefore, a principal should be someone who is devout in practicing his religion. Moreover, he must be able to practice his religion properly and be able to carry out religious values in his life at school. Thus, the principal can be a role model for teachers, employees, and students.

\section{CONCLUSSION}

Based on the results of data analysis can be drawn some conclusions as follows: first, the principals were good at social and personality competences, yet were adequate at managerial, entrepreneurial, and supervision competences; second, the principals had comprehended the values of Sistem Among and even some principals had implemented them. However, they had not yet understood the leadership values based on Asta Brata and Sastra Gending. In relation to the findings of this study, it is necessary to train more prospective principals and principals to improve the principal's competence. Most of the principals who become research respondents have attended the training, but they are generally still difficult to master the required competencies. This indicates that the training appears to be ineffective. Therefore, it is necessary to improve the training for the principal. Future principal 
training needs to be evaluated which things need improvement. In addition, training can be done by emphasizing aspects of the application rather than the theoretical aspect. Training also needs to involve relevant institutions, training materials need to be made more varied, training models such as on the job training or apprenticeships to principals who are categorized as excellent should be done, and others. Future research needs to be done by identifying factors related to the principal's competence, as well as the impact of the principal's competence on school performance.

\section{REFERENCES}

Bandura, A. (1986). Social foundations of thought and action: A social cognitive theory. Englewood Cliffs, NJ: Prentice Hall.

Boyatzis, R. E. (1982). The competent manager: A model of effective performance. New York, NY: Willey.

Browne-Ferrigno, T., \& Muth, R. (2004). Leadership mentoring in clinical practice: Role socialization, professional development, and capacity building. Educational Administration Quarterly, 40(4), 468-494. doi:10.1177/0013161X04267113.

Cerado, E. C., \& Abdullah, S. N. (2015). Emotional intelligence and social competence: Antecedents of school administrators' transformational leadership qualities. Journal of US-China Public Administration, 12(3), 180-184. do i: $10.17265 / 15486591 / 2015.03 .002$.

Demir, K. (2008). Transformational leadership and collective efficacy: The moderating roles of collaborative culture and teachers' self-efficacy. Eurasian Journal of Educational Research, 33, 93-112.

Departemen Pendidikan Nasional. (2007). Kewirausahaan sekolah (Materi diklat pembinaan kompetensi calon kepala sekolah/kepala sekolah).
Dewantara, K. H. (1930, February). Pengajaran nasional pendirian dan sifat Taman Siswa. Pidato Pada Rapat Umum Taman Siswa, Malang, Indonesia.

Goleman, D., Boyatzis, R. E, \& McKee, A. (1995). Primary leadership: Realizing the power of emotional intellegence. Boston, MA: Harvard Business School Publishing.

Halbusia, H. A., Tehseen, S., \& Ramayah, T. C. (2017). The impact of organizational justice on the ethical leadership under the moderating influence of perceived support: A conceptual study. Malaysian Journal of Business and Economics, 4(1), 46-64.

Harto, S. P. (2014). Politik pendidikan Indonesia dalam abad ke-21. Cakrawala Pendidikan, 33(3), 324-337. doi:10.21831/ cp.v3i3.2377.

Kaihatu, T. S. \& Rini, W. A. (2007). Kepemimpinan transformasional dan pengaruhnya terhadap kepuasan atas kualitas kehidupan kerja komitmen organisasi dan perilaku ekstra peran: Studi pada guru-guru SMU di kota Surabaya. Jurnal Manajemen dan Kewirausahaan, 98(1), 49-61. doi:10.9744/jmk.9.1.pp.\%20 49-61.

Kementrian Pendidikan dan Kebudayaan. (2013). Kompetensi supervisi kepala sekolah masih perlu ditingkatkan. Retrieved from https://www.kemdikbud.go.id/.

Kin, T. M., Kareem, O. A., Nordin, M. S., \& Bing, K. W. (2017). Principal change leadership competencies and teacher attitudes toward change: The mediating effects of teacher change beliefs. International Journal of Leadership in Education, 21(4), 1-20. doi: 10.1080/13603124.2016.1272719.

Leithwood, K. \& Jantzi, D. (1999). Transformational school leadership effects: A replication. School Effectiveness \& School Improvement, 10(4), 451-479. doi:10.1076/sesi.10.4.451.3495. 
Leithwood, K., \& Jantzi, D. (2006). Transformational school leadership for large-scale reform: Effects on students, teachers, and their classroom practices. School Effectiveness and School Improvement, 17(2), 201-227. doi:10.1080/ 09243450600565829.

Leksono, S. M., Rustaman, N., \& Redjeki, S. (2015). Pengaruh penerapan program perkuliahan biologi konservasi berbasis kearifan lokal terhadap kemampuan literasi biodiversitas mahasiswa calon guru. Cakrawala Pendidikan, 34(1), 8996. doi:10.21831/cp.v1i1.4179.

Macneil, A. J., Prater, D. L., \& Busch, S. (2009). The effects of school culture and climate on student achievement. International Journal of Leadership in Education, 12(1), 73-84. doi:10.1080/13603120701576241.

Miles, M. B., Huberman, A. M., \& Saldana, J. (2014). Qualitative data analysis: A methods sourcebook. Washington, DC: Sage Publications.

Reave, L. (2005). Spiritual values and practices related to leadership effectiveness. The Leadership Quarterly, 16(2005), 655687. doi:10.1016/j.leaqua.2005.07.003.

RoI, Ministrial Regulation of National Education 2007 No. 13, Competency Standards of School/Madrasah Principals.

Saxe, D. (2011). The relationship between transformational leadership and the emotional and social competence of the school leader (Doctoral Dissertations, Loyola University Chicago). Retrieved from http://ecommons.luc.edu/.

Sumardjoko, B. (2018). Model of civic education learning based on the local wisdom for revitalizing values of Pancasila. Cakrawala Pendidikan, 37(2), 201-211. doi:10.21831/cp.v37i2.18037.

Tian, M., Risku, M., \& Collin, K. (2015). A meta-analysis of distributed leadership from 2002 to 2013. Theory development, empirical evidence, and future research focus. Educational Management, Administration, and Leadership, 44(1), 146-164. doi:10.1177/1741143214558576.

Trevino, L. K. (1986). Ethical decision making in organizations: A person-situation interactionist model. Academy of management review, 11(3), 601-617. doi:10.2307/258313.

Wagiran, W. (2011). Pengembangan model pendidikan kearifan lokal dalam mendukung visi pembangunan Provinsi Daerah Istimewa Yogyakarta 2020. Jurnal Penelitian dan Pengembangan, III(3), 85100.

Wulandari, W. T., \& Mundilarto, M. (2016). Pengembangan perangkat pembelajaran fisika aktif tipe learning tournament berbasis local wisdom. Cakrawala Pendidikan, 35(3),365-377. doi:10.21831/ cp.v35i3.10433. 